\title{
Research \\ Genetic diversity of Ottelia acuminata (Hydrocharitaceae) from the Eastern Himalayas, revealed by ISSR markers
}

\author{
Chunlin Long ${ }^{1 *}$, Zhutan Jiang ${ }^{2}$, Zhiling Dao ${ }^{3}$ \\ ${ }^{1}$ College of Life and Environmental Sciences, Minzu University of China, Beijing 100081, China; and Kunming Institute of \\ Botany, Chinese Academy of Sciences, Kunming 650204, China; Email: Iong@mail.kib.ac.cn \\ ${ }^{2}$ Kunming Institute of Botany, Chinese Academy of Sciences, Kunming 650204, China; and Graduate University, Chinese \\ Academy of Sciences, Beijing 100049, China; Email: jiangzht@21cn.com \\ ${ }^{3}$ Kunming Institute of Botany, Chinese Academy of Sciences, Kunming 650204, China; Email: daozhl@mail.kib.ac.cn
}

\begin{abstract}
Ottelia acuminata (Gagnep.) Dandy (Hydrocharitaceae), an endangered aquatic species, was investigated in the Eastern Himalayas, especially in Yunnan Province of Southwest China. The genetic diversity among seven populations was examined using inter-simple sequence repeat (ISSR) amplification markers. The field survey showed that $43.5 \%$ natural populations of $O$. acuminata have become extinct during the last 30 years. Among 13 remaining wild populations, eight (61.5\%) are on the edge of extinction and only five (38.5\%) were unaffected. For the study on seven populations based on ten primers, 147 clear and reproducible DNA fragments were generated, of which 144 (97.96\%) were polymorphic. Within populations, however, the polymorphic bands (PPB) generated by ISSRs was 53 and occupied $36.05 \%$ in population B, and similarly within population J (51 and $34.69 \%$, respectively). The results showed that genetic variation is much higher among populations of $O$. acuminata than within populations. Analyses of Nei's gene diversity, genetic distance and Shannon's index also agreed with these results. The average value of Nei's gene diversity $(h)$ equaled 0.3710 . The coefficient of genetic differentiation (Gst) equaled 0.5487 , which means that $54.87 \%$ of the total molecular variance existed among populations. Such a high level of divergence present among populations may be caused by the complex topography and separated habitats which effectively restrict gene flow. Moreover, there is a lack of significant association between genetic and geographical distances $(r=0.28889, P>0.05)$ in the populations of $O$. acuminata. Therefore, we proposed an appropriate strategy for conserving the genetic resources of $O$. acuminata in the Eastern Himalayas; namely, rescuing and conserving the core populations in situ, while selecting and preserving more populations with fewer individuals from each population ex situ.
\end{abstract}

Key-words: Ottelia acuminata, genetic diversity, conservation, Eastern Himalayas, Yunnan Plateau, China

\section{Introduction}

Ottelia (Hydrocharitaceae), with 21 species in the genus, is distributed in the warmer environment worldwide (13 species in Africa, seven in Asia and Oceania, and one in South America) (Cook et al. 1984). All the species in the genus are aquatic and are confined to freshwater. Ottelia acuminata is distributed in western China and occurs in Guizhou, Sichuan and Yunnan

*Corresponding author, e-mail address: long@mail.kib.ac.cn provinces (Li 1981). It can be found in lakes, ponds and ditches. It can also tolerate slowly flowing water, and occurs in streams and rivers but absent in the fast flowing parts. Sometimes it can be grown in man-made waters, such as ricefields, and pools for the cultivation of Nelumbo or Trapa. The altitude of its distribution areas varies from ca. 600 to 3,000 meters above sea level. Mostly it grows to a depth of $2.5 \mathrm{~m}$ under water surface. But in Luguhu Lake, where a variety occurs, $O$. acuminata var. crispa, it can grow up to 5 m deep (Li and Hsu 1979). The substrate is usually clay or 
sand, but in Luguhu Lake it grows in gravel. It is confined to calcareous waters with a $\mathrm{pH}$ of 7-8.4, and is absent from acidic or basic waters (Li 1987). The most frequent species associated with O. acuminata are Potamogeton lucens L., Myriophyllum spicatum L., Potamogeton malaianus Miq., Potamogeton perfolianus L., Limnophila sessiliflora Bl. and Nymphaea tetragona Georgi. In deep water the commonest associates are Hydrilla verticillata (L.f.) Royle, Najas minor (Pers.) All. and Chara sp. In most habitats O. acuminata is not present in large quantities (Li 1980). Usually it grows in groups of 2-3 individuals together. The leaves of such a group cover an area of ca. 2-4 $\mathrm{m}^{2}$. The leaf laminas usually remain equally long on mature plants irrespective of the water depth, but the petioles vary enormously and may reach a length of 2-3 m (Cook and Urmi-Konig 1984). The laminas remain below the surface, while in shallow water the laminas may touch the surface of the water, but never floating. The flowers are borne above the water surface and the peduncles may reach the enormous length of $6 \mathrm{~m}$. After fertilization the peduncles usually but not always become spiral and withdraw the developing fruits under water. Although the female spathes may contain up to 12 flowers, rarely more than 4 or 5 develop into ripe, seed-bearing fruits. The stem remains corm-like; there are no runners, stolons or specialized hibernacula, with the exception of a few individuals (in Changhu Lake and Xihu Lake) which bear bulbils in the male spathes ( $\mathrm{Li} \mathrm{1981;} \mathrm{Li}$ 1988; He 1991).

Ottelia acuminata is an ornamental, medicinal and tasty edible plant as well. The leaves, peduncles and spathes are gathered and sold in the markets to be eaten as vegetables by the local people. O. acuminata was the commonest aquatic plant on Yunnan Plateau 50 years ago (Ley et al. 1963). It is very sensitive to pollution, excessive collecting and the ravages of the imported grass carp (Ctenopharyngodon idella Val.). Since 1987, Ottelia acuminata has been recognized as an endangered species by the Chinese authorities (SEPA and IBCAS 1987). In recent years it has become extinct in some localities and very rare in others.

Thus, it is essential to protect this native and endangered species, and its genetic variation as well. Suitable molecular markers are necessary to reliably assess genetic diversity to investigate the population genetic structure of $O$. acuminata so that appropriate strategies can be adopted for its genetic improvement, restoration, conservation, and sustainable management.
The use of inter-simple sequence repeats (ISSRs) is a microsatellite-derived genetic fingerprinting method based on the amplification of DNA segments occurring in the genome in regions where a particular SSR (short sequence repeat) motif occurs on opposing strands within a short and amplifiable distance (Zietkiewicz et al. 1994). This method is similar to RAPDs, since both require no prior knowledge of the genome, cloning or specific primer design, yet it has higher reproducibility than RAPDs because of high annealing temperatures, and the cost of the analyses is lower than the cost of AFLPs (Zietkiewicz et al. 1994; Reddy et al. 2002). Therefore, ISSRs have been broadly and successfully used in studies on genetic diversity, phylogenetics, genetic mapping and evolutionary biology in a wide range of plant species (Ajibade et al. 2000; Chapman et al. 2000; Sankar and Moore 2001; Cheghamirza et al. 2004).

We have engaged in collection and genetic diversity analysis of Ottelia acuminata occurring in the Eastern Himalayas, especially on the Yunnan Plateau, since 2002. The present study included a detailed field survey of the population distribution of $O$. acuminata in Yunnan. And we tested the usability of ISSR primers to investigate the level and distribution of genetic diversity in seven natural populations of $O$. acuminata. Finally, we used 10 out of the 96 ISSR primers tested. The aim was to understand the changing distribution patterns, to reveal the genetic variation within and among populations of O. acuminata at the level of

Table 1. List of populations of Ottelia acuminata used in this study.

\begin{tabular}{|c|c|c|c|}
\hline $\begin{array}{l}\text { Popul } \\
\text { ation }\end{array}$ & Population localities & $\begin{array}{l}\text { Water } \\
\text { System }\end{array}$ & $\begin{array}{l}\text { Longitude(E)/ } \\
\text { Latitude }(N)\end{array}$ \\
\hline B & $\begin{array}{l}\text { Heilongtan Spring, } \\
\text { Baiyi village, Songming } \\
\text { County, Yunnan }\end{array}$ & $\begin{array}{l}\text { Jinsha } \\
\text { River }\end{array}$ & $\begin{array}{l}102^{\circ} 52^{\prime} / \\
25^{\circ} 16^{\prime}\end{array}$ \\
\hline $\mathrm{N}$ & $\begin{array}{l}\text { Luguhu Lake, Ninglang } \\
\text { County, Yunnan }\end{array}$ & $\begin{array}{l}\text { Jinsha } \\
\text { River }\end{array}$ & $\begin{array}{l}100^{\circ} 49^{\prime} / \\
27^{\circ} 42^{\prime}\end{array}$ \\
\hline S & $\begin{array}{l}\text { Changhu Lake, Shilin } \\
\text { County, Yunnan }\end{array}$ & Zhu River & $\begin{array}{l}103^{\circ} 23^{\prime} / \\
24^{\circ} 42^{\prime}\end{array}$ \\
\hline $\mathrm{T}$ & $\begin{array}{l}\text { Beihai wetland, } \\
\text { Tengchong County, } \\
\text { Yunnan }\end{array}$ & $\begin{array}{l}\text { Yiluowadi } \\
\text { River }\end{array}$ & $\begin{array}{l}98^{\circ} 33^{\prime} / \\
25^{\circ} 07^{\prime}\end{array}$ \\
\hline $\mathrm{L}$ & $\begin{array}{l}\text { Lashihai Lake, } \\
\text { Gucheng District, } \\
\text { Yunnan }\end{array}$ & $\begin{array}{l}\text { Jinsha } \\
\text { River }\end{array}$ & $\begin{array}{l}100^{\circ} 09^{\prime} / \\
26^{\circ} 53^{\prime}\end{array}$ \\
\hline G & $\begin{array}{l}\text { Gemei River, Jianchuan } \\
\text { County, Yunnan }\end{array}$ & $\begin{array}{l}\text { Lancang } \\
\text { River }\end{array}$ & $\begin{array}{l}100^{\circ} 11^{\prime} / \\
26^{\circ} 37^{\prime}\end{array}$ \\
\hline $\mathrm{J}$ & $\begin{array}{l}\text { Heilongtan Spring, } \\
\text { Xinhua village, Heqing } \\
\text { County, Yunnan }\end{array}$ & $\begin{array}{l}\text { Jinsha } \\
\text { River }\end{array}$ & $\begin{array}{l}99^{\circ} 55^{\prime} / \\
26^{\circ} 28^{\prime}\end{array}$ \\
\hline
\end{tabular}




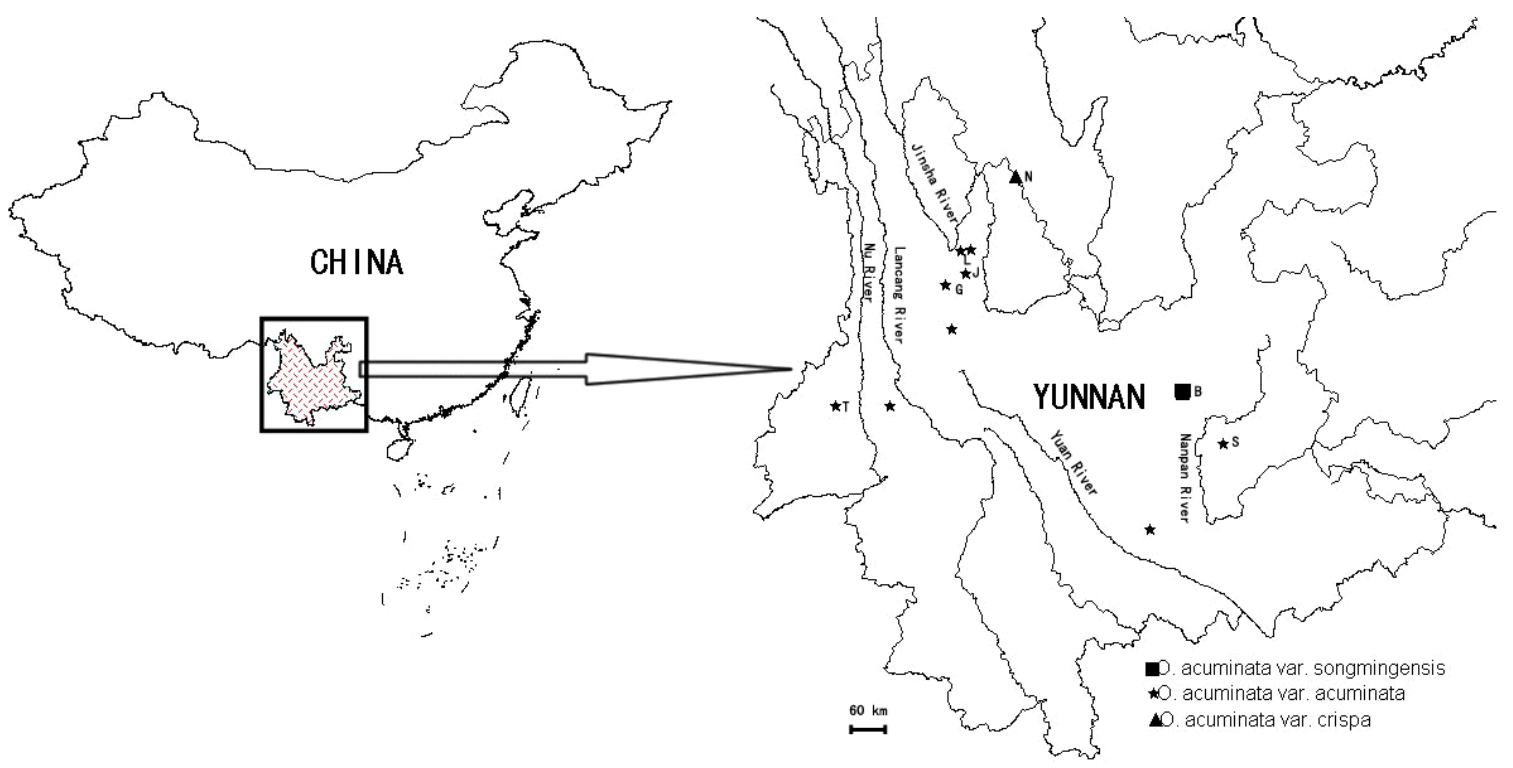

Figure 1. Distribution map of Ottelia acuminata populations.

DNA, and to find an effective method to conserve (both in situ and ex situ) and collect (sampling) this endangered species.

\section{Materials and Methods}

\section{FIELD INVESTIGATION AND SAMPLING}

From 2002 to 2005, we investigated the distribution pattern and extent of $O$. acuminata in Yunnan and found that the natural populations mainly remained in three regions: Lijiang, Dali and Kunming. According to the field survey, a total of 13 wild populations of $O$. acuminata have been approved to survive in the natural habitats (Figure 1). Seven natural populations of $O$. acuminata were sampled (Table 1 ). These populations were divided into four groups by water system: Jinsha River (i.e. the Yangtze) (B, N, L, J), Lancang River (the Mekong) (G), Zhu River (the Pear) (S) and Yiluowadi River (the Irrawaddy) (T). In each of the seven populations, 20 individual separated by a distance of more than five meters were collected and planted in a pool located at the Botanical Garden of the Kunming Institute of Botany.

\section{TOTAL DNA EXTRACTION}

Genomic DNA of the samples collected from seven populations was extracted using SDS improved protocol (Cheng et al. 2004). About $1.0 \mathrm{~g}$ dried leaf was ground in a mortar with liquid nitrogen and incubated for $30 \mathrm{~min}$ at $65^{\circ} \mathrm{C}$ in $1.5 \mathrm{ml}$ of SDS extraction buffer $(100 \mathrm{mM}$ Tris-HCl, $\mathrm{pH}$ 8.0, $500 \mathrm{mM} \mathrm{NaCl}, 50 \mathrm{mM}$ EDTA, pH 8.0, $10 \mathrm{mM}$ mercaptoethanal) and $600 \mu \mathrm{l} 20 \%$ SDS. To the previous solution, $2 \mathrm{ml}$ of $5 \mathrm{M}$ potassium acetate ( $\mathrm{pH} 7.5$ ) was included and subsequently mixed. After 30 min incubation in an icewater bath, the mixture was centrifuged at $11,400 \times \mathrm{g}$ for 10 $\min$ at $4^{\circ} \mathrm{C}$. The supernatant was mixed with an equal volume of chloroform-isoamyl alcohol (CI, 24:1) and centrifuged at $11,400 \times \mathrm{g}$ for $10 \mathrm{~min}$ at $4^{\circ} \mathrm{C}$. The uppermost light solution was moved to a new tube and 0.6 volume cold isopropanol

Table 2. The nucleotide sequences of the ten selected primers, and the numbers of bands scored.

\begin{tabular}{llll}
\hline Primer & $\begin{array}{l}\text { Primer } \\
\text { sequence } \\
\left(5^{\prime}-3^{\prime}\right)\end{array}$ & $\begin{array}{l}\text { Annealing } \\
\text { temperature } \\
\left({ }^{0} \mathrm{C}\right)\end{array}$ & $\begin{array}{l}\text { Number of } \\
\text { bands } \\
\text { recorded }\end{array}$ \\
\hline UBC816 & $(\mathrm{CA})_{8} \mathrm{~T}$ & 52.7 & 14 \\
UBC827 & $(\mathrm{AC})_{8} \mathrm{G}$ & 54.6 & 15 \\
UBC846 & $(\mathrm{CA})_{8} \mathrm{RT}$ & 52.7 & 20 \\
UBC849 & $(\mathrm{GT})_{8} \mathrm{YA}$ & 52.7 & 13 \\
UBC850 & $(\mathrm{GT})_{8} \mathrm{YC}$ & 55.0 & 17 \\
UBC855 & $(\mathrm{AC})_{8} \mathrm{YT}$ & 52.7 & 12 \\
UBC856 & $(\mathrm{AC})_{8} \mathrm{YA}$ & 52.7 & 11 \\
UBC857 & $(\mathrm{AC})_{8} \mathrm{YG}$ & 55.0 & 16 \\
$\mathrm{UBC} 873$ & $(\mathrm{GACA})_{4}$ & 51.6 & 14 \\
UBC889 & $\mathrm{DBD}(\mathrm{AC})_{7}$ & 49.8 & 15 \\
\hline
\end{tabular}


was added. The tube was stirred carefully and put on the ice for 30 min for precipitation of the DNA. The DNA was recovered as a pellet by centrifugation at $11,400 \times \mathrm{g}$ for 10 $\min$ at $4^{\circ} \mathrm{C}$, washed twice with cold $70 \%$ ethanol. When the DNA pellet had air-dried at room temperature, it was dissolved in $200 \mu \mathrm{l}$ TE (10 mM Tris-HCl, pH 8.0, 1 mM EDTA, pH 8.0 ) and $3 \mu \mathrm{l}$ of $10 \mathrm{mg} / \mathrm{ml}$ of RNAase, and put in a water bath at $37^{\circ} \mathrm{C}$ for $1 \mathrm{~h}$. Twenty microliters of $3 \mathrm{M}$ sodium acetate ( $\mathrm{pH}$ 5.2) was added and then mixed. The DNA was again precipitated by adding $200 \mu \mathrm{l}$ cold isopropanol. After centrifuging at $11,400 \times \mathrm{g}$ for $10 \mathrm{~min}$ at $4^{\circ} \mathrm{C}$, the pellet was washed with cold $70 \%$ ethanol, air-dried and resuspended in $100 \mu \mathrm{l} \mathrm{TE}$ buffer. The DNA samples isolated were diluted to $200 \mathrm{ng} / \mu \mathrm{l}$ and stored at $-20^{\circ} \mathrm{C}$.

ISSR PCR AMPLIFICATION AND SELECTION OF OPTIMUM PRIMERS

A total of 96 ISSR primers obtained from Shengong Inc. were screened and 10 primers (Table 2) were selected for the ISSR analysis of $O$. acuminata based on the reproducible band. All amplifications were performed in an Eppendorf Mastercycler gradient PCR system (Eppendorf AG, 22331 Hamburg, Germany). The amplification reactions were performed in a volume of $25 \mu \mathrm{l}$ containing $2 \mathrm{mM} \mathrm{Mg}{ }^{2+}, 0.2 \mathrm{mM}$ dNTP (Promega), $0.45 \mu \mathrm{M}$ primer, $0.5 \mathrm{U}$ Taq polymerase (Promega Co., USA), $2.5 \mu \mathrm{l}$ of the $10 \times$ reaction buffer and $20 \mathrm{ng}$ of genomic DNA. PCR amplification was performed as follows: initial $5 \mathrm{~min}$ at $94^{\circ} \mathrm{C}$, followed by 40 cycles of $45 \mathrm{~s}$ at $94^{\circ} \mathrm{C}$, $45 \mathrm{~s}$ at $49-55^{\circ} \mathrm{C}, 90 \mathrm{~s}$ at $72^{\circ} \mathrm{C}$, and a final 7 min extension at $72^{\circ} \mathrm{C}$. The PCR products were separated on $1.5 \%$ agarose gels and stained by $0.1 \%$ ethidium bromide. The molecular weights were estimated using the E105-2 100 bp DNA Ladder Plus (Yunke Bio. Co. Ltd., China). The gel images were recorded and the band sizes were quantified using an E-box Fluorescence imaging system (Vilber Lourmat, France). The majority of the plant-primer combinations were run more than once to ensure reproducibility.

\section{DATA ANALYSIS}

ISSR amplified fragments, with the same mobility according to the molecular weight (bp), were scored manually for band presence (1) or absence (0). The following parameters were generated using the program POPGENE 1.32 (Yeh et al. 1997) to describe intra and inter-population genetic variation: Nei's gene diversity (h), Shannon's information index (I), the observed number of alleles (na) and the effective number of alleles (ne) (Lewontin 1972; Nei 1973). Genetic divergence between populations was investigated using Nei's genetic distances (GD) and genetic identities (GID) (Nei 1978). Nei's genetic distances were calculated for all population pairs, using the NTSYS-pc v. 2.1 (Rohlf 1998) to construct a dendrogram using the unweighted pair group method (UPGMA). The genetic structure was further investigated using Nei's gene diversity statistics, including the total genetic diversity (Ht), genetic diversity within populations (Hs), and the relative magnitude of genetic differentiation among populations (Gst) (Nei 1973). An estimate of gene flow among populations $(\mathrm{Nm})$ was computed using the formula of McDermott and McDonald Nm = (1-Gst)/2Gst (McDermott and McDonald 1993). Using the NTSYS-pc v. 2.1 to make a Mantel test (Mantel 1967), it was used to test whether the matrix of genetic distances correlated with the matrix of geographical distances.

\section{Results}

During 2002-2005, we have made an extensive survey on $O$. acuminata in the Eastern Himalayas, especially on the Yunnan Plateau, including its current distribution, population characteristics and status of endangerment. The field survey indicated that there are 13 wild populations of O. acuminata remaining. These populations occupied an area ranged from 50 to $50,000 \mathrm{~m}^{2}$ with an elevation between 1,515 and 2,730 $\mathrm{m}$. Contrasting to 23 population numbers recorded during 1978-1982 (Li 1980; Li 1987), 10 (43.5\%) natural populations of $O$. acuminata on Yunnan Plateau had disappeared in the past 30 years. In the existing 13 populations, 8 (61.5\%) have been disturbed seriously and are on the verge of extinction, and only 5 (38.5\%) grow normally.

A summary of the genetic data for between seven $O$. acuminata populations is given in Table 3. Among seven populations, 10 ISSR primers amplified 147 bands and 144 bands (PPB 97.96\%) were found to be polymorphic. A total of 147 bands ranging from 200 to 1,800 bp were scored, corresponding to an average of 14.7 bands per primer. In individual populations, the percentages of polymorphic bands (PPB) ranged from $34.69 \%$ to $55.78 \%$, with an average of 46.74\% (Table 3). Nei’s gene diversities (h) varied from 0.1072 to 0.2062 , with an average of 0.1675 , and Shannon's indices (I) ranged from 0.1647 to 0.3045 , with an average of 0.2493 . 
Table 3. The genetic diversity of Ottelia acuminata and genetic structure of its populations.

\begin{tabular}{|c|c|c|c|c|c|c|c|c|c|}
\hline Population & na & ne & $h$ & $I$ & $P P B$ & $H t$ & $H s$ & Gst & $\mathrm{Nm}$ \\
\hline B & 1.3605 & 1.2203 & 0.1303 & 0.1943 & 36.05 & & & & \\
\hline $\mathrm{N}$ & 1.4694 & 1.2945 & 0.1714 & 0.2542 & 46.94 & & & & \\
\hline$S$ & 1.5510 & 1.3593 & 0.2062 & 0.3045 & 55.10 & & & & \\
\hline $\mathrm{T}$ & 1.5306 & 1.3092 & 0.1802 & 0.2699 & 53.06 & & & & \\
\hline $\mathrm{L}$ & 1.5578 & 1.3560 & 0.2048 & 0.3033 & 55.78 & & & & \\
\hline G & 1.4558 & 1.2982 & 0.1721 & 0.2544 & 45.58 & & & & \\
\hline J & 1.3469 & 1.1737 & 0.1072 & 0.1647 & 34.69 & & & & \\
\hline Mean & 1.4674 & 1.2873 & 0.1675 & 0.2493 & 46.74 & & & & \\
\hline Total & 1.9796 & 1.6514 & 0.3710 & 0.5462 & 97.96 & 0.3710 & 0.1674 & 0.5487 & 0.4113 \\
\hline
\end{tabular}

$n a=$ Observed number of alleles; $n e=$ Effective number of alleles; $h=$ Nei's (1973) gene diversity; $I=$ Shannon's Information index; $P P B=$ percentage of polymorphic bands; $H t=$ Total genetic diversity for the species; $H s=$ The mean heterozygosity within populations; $G s t=$ Coefficient of gene differentiation; $\mathrm{Nm}=$ Estimate of gene flow.

Table 4. Nei’s genetic identity (above diagonal) and genetic distance (below diagonal) among 7 natural Ottelia acuminata populations by ISSR markers.

\begin{tabular}{|c|c|c|c|c|c|c|c|}
\hline Population & B & $\mathrm{N}$ & S & $\mathrm{T}$ & $\mathrm{L}$ & G & $\mathrm{J}$ \\
\hline B & * & 0.6889 & 0.6977 & 0.6621 & 0.6711 & 0.6434 & 0.6235 \\
\hline $\mathrm{N}$ & 0.3726 & $*$ & 0.7295 & 0.6502 & 0.7587 & 0.6988 & 0.6820 \\
\hline$S$ & 0.3600 & 0.3154 & $*$ & 0.7868 & 0.8006 & 0.6882 & 0.7366 \\
\hline $\mathrm{T}$ & 0.4123 & 0.4304 & 0.2398 & * & 0.7621 & 0.6980 & 0.6802 \\
\hline $\mathrm{L}$ & 0.3988 & 0.2761 & 0.2224 & 0.2716 & $*$ & 0.7680 & 0.8055 \\
\hline G & 0.4409 & 0.3584 & 0.3737 & 0.3596 & 0.264 & $*$ & 0.7997 \\
\hline J & 0.4724 & 0.3827 & 0.3057 & 0.3854 & 0.2162 & 0.2236 & * \\
\hline
\end{tabular}

Table 5. Geographic distance among 7 natural Ottelia acuminata populations.

\begin{tabular}{lcccccc}
\hline Populations & B & N & S & T & L & G \\
\hline B & & & & & & \\
N & 342.0 & & & & & \\
S & 84.9 & 423.8 & & & & \\
T & 435.6 & 365.5 & 492.2 & & & \\
L & 329.4 & 114.0 & 410.8 & 249.8 & & \\
G & 324.5 & 162.5 & 387.4 & 205.5 & 47.2 & \\
J & 309.0 & 135.9 & 391.3 & 232.8 & 28.8 & 27.5 \\
\hline
\end{tabular}

Moreover, the values of the parameters $h$ and I showed a similar trend. The mean observed number of alleles (na) ranged from 1.3469 to 1.5578 , while the mean effective number of alleles (ne) varied from 1.1737 to 1.3593. When calculated across populations, the $\mathrm{h}$ and I values equaled 0.3710 and 0.5462, respectively, and the na and ne values equaled 1.9796 and 1.6514, respectively. Among the seven populations investigated, population $\mathrm{S}$ exhibited the highest level of variability while population $\mathrm{J}$ possessed the lowest value of variability.

The analysis of the population genetic structure revealed a considerable level of genetic differentiation among the seven populations of $O$. acuminata investigated. The total gene diversity $(\mathrm{Ht})$ and gene diversity within populations (Hs) were 0.3710 and 0.1647 , respectively. The coefficient of genetic differentiation (Gst), equaling 0.5487, indicated a high 
degree of genetic differentiation among populations. The level of gene flow (Nm, the number of migrating individuals among populations per generation) was estimated to be only 0.4113 .

The genetic distances, based on the allele frequencies of the ISSR markers, were calculated for each pair of populations to estimate the extent of their divergence (Table 4). The average genetic distance between populations was equal to 0.3372 . The greatest genetic distance values were found between population B and other populations. This result revealed that population B, located geographically the furthest away from the other populations, is also genetically the most distant. However, Mantel's test showed that there was no significant correlation between genetic and geographical distances (Table 5) $(r=0.28889, \mathrm{P}>0.05)$ among the seven populations of $O$. acuminata.

A cluster analysis (UPGMA) was used to generate a dendrogram based on Nei's genetic distances of ISSR markers among seven populations (Figure 2). The dendrogram indicated that the population $\mathrm{B}$ of var. songmingensis and the population $\mathrm{N}$ of var. crispa was clearly separated from all other populations, while the five populations of var. acuminata clustered as a clade. The two populations (L, J) from Jinsha River clustered together before forming a cluster with any other population. In each cluster, individuals from the same population formed a distinct group. Overall, clusters were not related to the geographic distance between populations.

\section{Discussion}

ENDANGERED STATUS AND REASON OF O. ACUMINATA

According to the survey during 1978-1982 (Li 1980; Li 1987), 23 natural populations of $O$. acuminata had been recorded in Yunnan. For preserving and utilizing the plant genetic resources, we investigated again the numbers, localities, population and status of endangerment from 2002 to 2005. This work showed that 13 wild populations remained and 10 had vanished. In addition, 8 surviving populations were seriously disturbed and endangered; only 5 maintained normal growth. The study also indicates that the factors causing the species endangered are mainly: reclaiming from lake marshes, waters pollution, excessive fishes farming or collecting in lakes, water conservancy projects, lake drought and excessive vegetable collecting. Therefore, we should preserve this threatened species, based on a better understanding of genetic diversity among and within populations is essential for its conservation.

\section{GENETIC DIVERSITY AMONG AND WITHIN POPULATIONS}

Yunnan is located in the Eastern Himalayas. It is one of the regions with the most plentiful biodiversity in China and has a wide range of climatic and geographic conditions. According to our field investigation, the ecological environments and geographic distribution patterns of O. acuminata in Yunnan

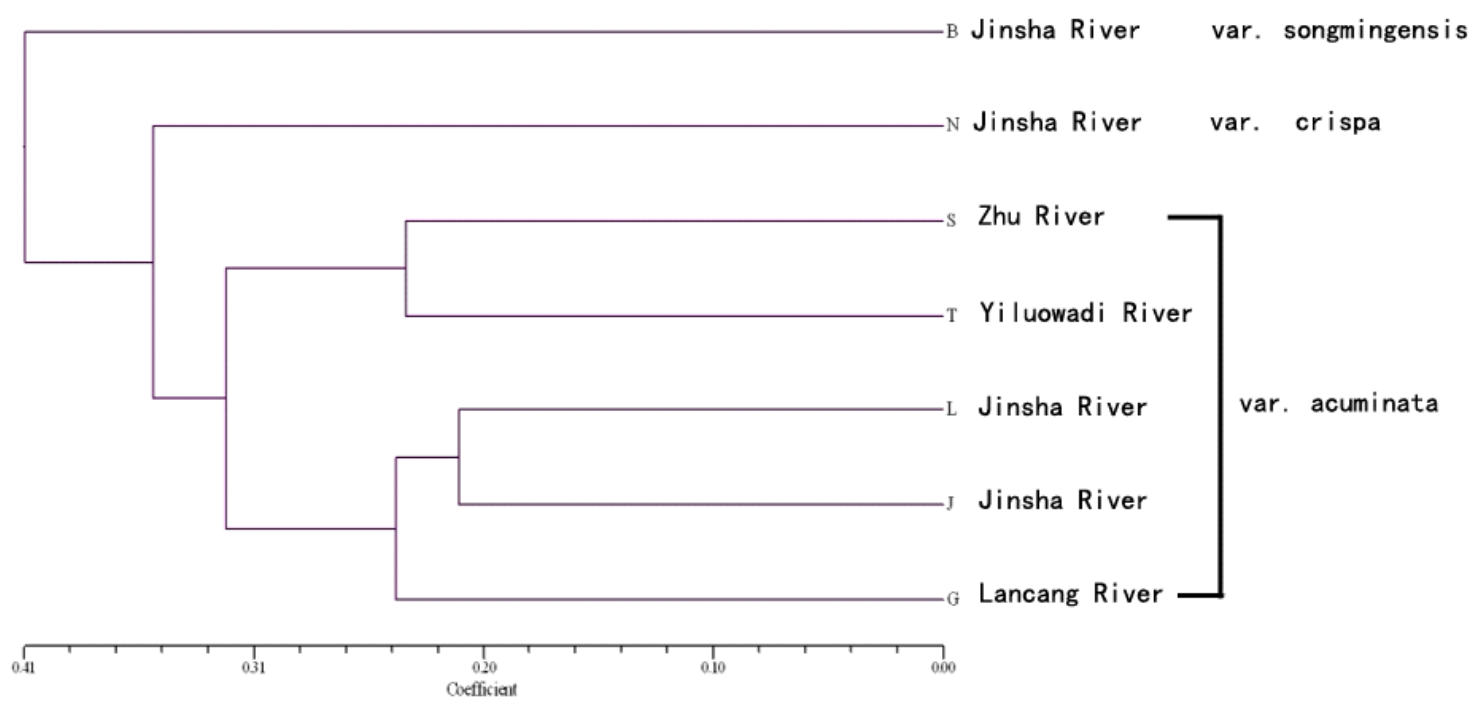

Figure 2. UPGMA dendrogram of populations of Ottelia acuminata based on Nei’s genetic distance. 
are diverse. Individuals among populations have different morphological characteristics. By using ISSR markers, this study showed that there is a high level of genetic diversity among populations of $O$. acuminata from Yunnan. This result agrees with previous studies based on allozyme analysis (He and Sun, 1992). Between seven populations, the percentages of polymorphic bands detected by ISSRs were 147 and $97.96 \%$. And relatively low genetic diversity existed within populations where PPB values ranged from $34.69 \%$ to $55.78 \%$, with an average of $46.74 \%$, implying that a larger proportion of variation resided among populations. Similarly, Nei's gene diversity (0.37), unbiased measures of genetic distance and Shannon's information index ( 0.55$)$ between populations were higher than that within populations. These analyses show that most of the genetic variations are partitioned between populations rather than within populations. The geographical and ecological differences in the distribution of genetic diversity of populations are extremely common. Many studies have clearly demonstrated that there is a clear association between population characteristics and the environments in which they occur (Aston and Bradshaw 1966; Al-Hiyaly et al. 1993). However, in this case, the evident genetic differentiation among populations of $O$. acuminata, genetic differentiation among populations does not appear to be correlated with geographic distance among the populations.

A high level of population differentiation may be explained by several factors, including the species' breeding system, genetic drift or genetic isolation of populations (Hogbin and Peakall 1999). When populations are small and isolated from one another, genetic drift influences genetic structure and increases differentiation among populations (Barrett and Kohn 1991; Ellstrand and Elam 1993). Low levels or absence of gene flow among populations is characteristic of many rare species (Slatkin 1985). Consequently, genetic differentiation among populations has been reported for a number of them (Sun and Wong 2001; Li et al. 2002). Nm, the effective gene flow per generation $(\mathrm{Nm}=0.4113)$, for $O$. acuminata was lower than one successful migrant per generation, indicating limited gene flow among populations. The low rate of natural recruitment observed today, together with increased habitat fragmentation and large distances between populations is seriously contributing to the substantial decrease or even lack of gene flow at the population level.

Studies on habitat fragmentation indicate that this process can lead to population extinction and the loss of genetic variation, by not only minimizing suitable habitats, but also increasing the mating opportunity between genetically closely related individuals. All of these factors could have contributed to a low level genetic diversity within populations of $O$. acuminata in the Eastern Himalayas.

\section{Conclusion}

A better understanding of the extent and patterns of genetic diversity of $O$. acuminata in the Eastern Himalayas, especially on the Yunnan Plateau, is essential for its conservation and sustainable uses. It will help us in determining what to conserve, and where and how to conserve this endangered species. The results from this work show that there is a high level of genetic diversity between populations but a low level genetic variation within populations. The loss of genetic diversity with extinction of populations is ever increasing.

We suggest that in situ conservation areas for five core $O$. acuminata populations growing normally should be established. A rational way for ex situ conservation is to collect and preserve the germplasm resources from eight populations disturbed seriously with relatively fewer individuals in each population.

\section{Acknowledgements}

The authors thank Prof. Heng Li for her valuable suggestions to the study and result discussions. We are grateful to Prof. Diqiu Yu and Dr. Lu Li for technical assistances. This study was supported by grants from the Ministry of Education of China through its 985 and 111 projects (MUC 98503-001006 \& B08044), the Chinese Academy of Sciences (KSCX2-YWZ-0925 \& O92441112F), the National Natural Science Foundation of China (31070288), the Japan Society for the Promotion of Science (JSPS/AP/109080), and the Ministry of Science and Technology of China (2008FY110400-2-2 \& 2005DKA21006).

\section{References}

Ajibade S.R., Weeden N.F. and Chite S.M. 2000. Inter simple sequence repeat analysis of genetic relationships in the genus Vigna. Euphytica 111: 47-55.

Al-Hiyaly S.A.K., McNeilly T. and Bradshaw A.D. 1993. The effect of zinc contamination from electricity pylons: genetic constraints on selection for zinc tolerance. Heredity 70: 22-32. 
Aston D.L. and Bradshaw A.D. 1966. Evolution in closely adjacent populations. Part II. Agrostis stolonifera in maritime habitats. Heredity 37: 9-25.

Barrett S.C.H. and Kohn J.R. 1991. Genetics and evolutionary consequences of small population size in plants: implications for conservation. In: Genetics and Conservation of Rare Plants (D.A. Falk and K.E. Holsinger, eds.), pp. 3-30. Oxford University Press, NY, USA.

Chapman H.M., Parh D. and Oraguzie N. 2000. Genetic structure and colonizing success of a clonal, weedy species, Pilosella officinarum (Asteraceae). Heredity 84: 401-409.

Cheghamirza K., Koveza O.V., Konovalov F.A. and Gostimskii S.A. 2004. Identification and mapping of chi115 gene and DNA markers linked to it in pea (Pisum sativum L.). Genetika 40: 909-915.

Cheng J.W., Zai Q.C., Xing Q.H., Shou H.Y., Kai M.C. and Chong R.S. 2004. Genetic diversity among and within populations of Oryza granulata from Yunnan of China revealed by RAPD and ISSR markers: implications for conservation of the endangered species. Plant Science 167: 35-42.

Cook C.D.K. and Urmi-Konig K. 1984. A revision of the genus Ottelia (Hydrocharitaceae): 2. the species of Eurasia Australasia and America. Aquatic Botany 20: 131-178.

Cook C.D.K., Symoens J.J. and Urmi-Konig K. 1984. A revision of the genus Ottelia (Hydrocharitaceae): 1. generic considerations. Aquatic Botany 18: 263-274.

Ellstrand N.C. and Elam D.R. 1993. Population genetics consequences of small population size: implications for plant conservation. Annual Review of Ecology Evolution and Systematics 24: 217-243.

He J.B. 1991. Systematic Botanical and Biosystematic Studies on Ottelia in China. Wuhan University Press, Wuhan.

He J.B. and Sun X.Z. 1992. Electrophoretic banding patterns of three isoenzymes of Chinese Ottelia and their systematic significance. Journal of Wuhan Botanical Research 10: 3542.

Hogbin P.M. and Peakall R. 1999. Evaluation of the conservation of genetic research to the management of endangered plant Zieria prostrata. Conservation Biology 13: 514-522.

Lewontin R.C. 1972. The apportionment of human diversity. Evolution Biology 6: 381-398.

Ley S.H., Yu M.K., Li K.C., Tseng C.M., Chen C.Y., Kao P.Y. and Huang F.C. 1963. Limnological survey of the lakes of Yunnan plateau. Oceanologia et Limnologia Sinica 5: 87114.

Li H. 1980. A study on the lake vegetation of Yunnan Plateau. Acta Botanica Yunnanica 2: 113-141.
Li H. 1981. Classification, distribution and phylogeny of the genus Ottelia. Acta Phytotaxonomica Sinica 19: 29-42.

Li H. 1987. The lake vegetation of Hengduan Mountains. Acta Botanica Yunnanica 9: 257-270.

Li H. 1988. The aquatic vegetation and flora in Changhu Lake. Journal of Yunnan University Suppl. 10: 119-123.

Li H., Hsu T.Z. 1979. The geobotanical expedition on Lake Luguhu. Acta Botanica Yunnanica 1: 125-137.

Li Q.M., Xu Z.F. and He T.H. 2002. Ex situ genetic conservation of endangered Vatica guangxiensis (Dipterocarpaceae) in China. Biological Conservation 106: 151-156.

Mantel N. 1967. The detection of disease clustering and a generalized regression approach. Cancer Research 27: 209-212.

McDermott J.M. and McDonald B.A. 1993. Gene flow in plant pathosystems. Annual Review of Phytopathology 31: 353373.

Nei M. 1973. Analysis of gene diversity in subdivided populations. Proceedings of the National Academy of Sciences of the United States of America 70: 3321-3323.

Nei M. 1978. Estimation of average heterozygosity and genetic distance from a small number of individuals. Genetics 89: 583-590.

Reddy M.P., Sarla N. and Siddiq E.A. 2002. Inter simple sequence repeat (ISSR) polymorphism and its application in plant breeding. Euphytica 128: 9-17.

Rohlf F.J. 1998. NTSYS-Numerical Taxonomy and Multivariate Analysis System. Exeter Publ., NY, USA.

Sankar A.A. and Moore G.A. 2001. Evaluation of inter-simple sequence repeat analysis for mapping in Citrus and extension of the genetic linkage map. Theoretical and Application Genetics 102: 206-214.

SEPA (State Environment Protection Administration), IBCAS (Institute of Botany, Chinese Academy of Sciences) 1987. List of Rare and Endangered Plants of China(vol. I). Science Press, Beijing.

Slatkin M. 1985. Gene flow in natural populations. Annual Review of Ecology Evolution and Systematics 16: 393-430.

Sun M. and Wong K.C. 2001. Genetic structure of three orchid species with contrasting breeding systems using RAPD and allozyme markers. American Journal of Botany 88: 21802189.

Yeh F.C., Yang R.C., Boyle T.B.J., Ye Z.H. and Mao J.X. 1997. POPGENE, the User-Friendly Shareware for Population Genetic Analysis. Molecular Biology and Biotechnology Centre, University of Alberta, Edmonton, Canada.

Zietkiewicz E., Rafalski A. and Labuda D. 1994. Genome fingerprinting by simple sequence repeat (SSR)-anchored polymerase chain reaction amplification. Genomics 20: 176183. 